\title{
Clostridium perenne and Clostridium paraperfringens: Later Subjective Synonyms of Clostridium barati
}

\author{
ELIZABETH P. CATO, LILLIAN V. HOLDEMAN, AND W. E. C. MOORE \\ Department of Anaerobic Microbiology, Virginia Polytechnic Institute and State University, Blacksbury, \\ Virginia 24061
}

\begin{abstract}
Identical electrophoretic patterns of cellular proteins were detected with ATCC 27638, ATCC 25782, and ATCC 27639, the type strains of Clostridium barati (Prévot 1938) Holdeman and Moore 1970, C. perenne (Prévot 1940) McClung and McCoy 1957, and C. paraperfringens Nakamura et al. 1970, respectively, all of which are cited in the Approved Lists of Bacterial Names. The morphological and biochemical reactions of these strains and of other reference strains of these species were also similar. On these bases, it is herein proposed that these three names are synonyms. According to the rules of the Bacteriological Code, in those cases in which names on the Approved Lists compete for priority, the priority is determined by the date of the original publication of the name before 1 January 1980. According to our interpretation of this rule, the specific epithet 'barati" has priority. The correct name of this organism, then, is Clostridium barati, and $C$. perenne and $C$. paraperfringens are later subjective synonyms.
\end{abstract}

During examinations of clostridial cellular proteins that were detected by polyacrylamide slab gel electrophoresis (7), we found that protein patterns produced from the type strains of C. barati (Prévot 1938) Holdeman and Moore 1970, C. paraperfringens Nakamura et al. 1970, and $C$. perenne (Prévot 1940) McClung and McCoy 1957 were identical. We therefore reexamined the phenotypic characteristics and the electrophoretic patterns of other strains in our collection that had been identified as members of these three species by the investigators who first described them.

\section{MATERIALS AND METHODS}

Bacterial strains. The strains studied and their sources and original designations are listed in Table 1. Those with only a VPI number had been identified in our laboratory by conventional phenotypic tests (3).

Electrophoresis. The electrophoretic method described by Moore et al. (7) was used to compare cellular proteins released from the bacterial cells. Organisms were incubated for $6 \mathrm{~h}$ in $5 \mathrm{ml}$ of brain heart infusion broth supplemented with $0.1 \%$ calcium carbonate.

Culture media and methods. For determinations of the physiological characteristics of the strains, prereduced, anaerobically sterilized media and anaerobic methods described in the Virginia Polytechnic Institute and State University Anaerobe Laboratory Manual (3) were used. Hydrogen sulfide production was tested in SIM (sulfide-indole-motility) medium (BBL Microbiology Systems, Cockeysville, Md.).

\section{RESULTS AND DISCUSSION}

Electrophoretic patterns of soluble proteins from cells in 6-h-old cultures of the strains examined are shown in Fig. 1. Patterns from two phenotypically similar species of saccharolytic clostridia, $C$. absonum and $C$. perfringens, are included.

Biochemical properties of strains of $C$. barati, $C$. perenne, and $C$. paraperfringens were found to be nearly as similar as the electrophoretic patterns and agreed in most respects with the properties given in the original descriptions. The discrepancies and variations that occurred are listed in Table 2. Although all the strains in this study reduced nitrate, this characteristic has been found to be variable among strains $(3,8)$.

Prévot described Inflabilis barati in 1938 (10) and assigned it to his new genus Inflabilis because it had central to subterminal spores and was not motile. The species was transferred to the genus Clostridium by Holdeman and Moore in 1970 (4). In 1940, Prévot described Acuformis perennis, a saccharolytic, nonmotile species that formed terminal spores (11). This species was placed in the genus Clostridium by McClung and McCoy in 1957 (6). We frequently had difficulty differentiating between these two species because the reported major difference was the location of the spores. Most strains of these species, including the labeled strains received from Prévot, sporulate very poorly, but all strains survive heating at $80^{\circ} \mathrm{C}$ for $10 \mathrm{~min}$. The appearance and location of spores depend not only on the medium used but also on the length 
TABLE 1. Bacterial strains examined

\begin{tabular}{|c|c|c|c|}
\hline $\begin{array}{l}\text { VPI } \\
\text { no. }\end{array}$ & $\begin{array}{c}\text { ATCC } \\
\text { no. }\end{array}$ & $\begin{array}{c}\text { Original } \\
\text { identification }\end{array}$ & Source and other numbers \\
\hline 4443 & $26738^{a}$ & Inflabilis barati & A. R. Prevot ${ }^{b}$ no. 2227 , canine renal epithelioma \\
\hline 4624 & & Inflabilis barati & A. R. Prevot no. 1236 , boil \\
\hline 4475 & $25782^{a}$ & $\begin{array}{l}\text { Acuformis perennis } \\
\text { (C. perenne })\end{array}$ & A. R. Prevot no. 11 16D, hog liver \\
\hline 6921 & & & Tucson Medical Center, boil on thigh \\
\hline 8204 & & & Florida State Health Dept., peritoneal fluid \\
\hline 9436 & & & VA Hospital, Sepulveda, CA \\
\hline 9919 & & & California State Health Dept., ear \\
\hline $6907 \mathrm{~A}$ & $27639^{a}$ & C. paraperfringens & S. Nakamura ${ }^{c}$ no. G, gas gangrene \\
\hline 6908 & & C. paraperfringens & S. Nakamura no. F1S 5 \\
\hline $6909 \mathrm{~A}$ & 26740 & C. paraperfringens & S. Nakamura no. $3-3$, normal human intestine \\
\hline 4846 & & Inflabilis lacustris & A. R. Prevot no. 12/16B \\
\hline $6903 \mathrm{~A}$ & 27635 & C. absonum & S. Nakamura no. HA9103, soil \\
\hline 13181 & $27555^{a}$ & C. absonum & S. Nakamura no. HA7103, soil \\
\hline 5694 & $13124^{a}$ & C. perfringens & Weilcome Lab no. CN 1491 \\
\hline
\end{tabular}

$a_{\text {Type strain (15) }}$

$b_{\text {Pasteur Institute, Paris, France }}$

${ }^{c}$ Kanazawa University, Kanazawa, Japan

of incubation, and they can vary markedly in the same preparation. The photograph accompanying the original description of $C$. perenne (11) shows spores that are definitely subterminal as well as some that might be considered terminal.

In 1970, Nakamura et al. (9) published a description of strains they had isolated from a case of gas gangrene, from normal human intestinal contents, and from soil. They named the species $C$. paraperfringens but did not designate a type strain. In 1973, in an expanded study of the properties of these strains (8) and in comparison with other saccharolytic strains of clostridia, they designated a type strain of $C$. paraperfringens and reported that this strain was genetically homologous by deoxyribonucleic acid (DNA)-DNA hybridization with reference DNA prepared from strain 2227 of $I$. barati Prévot (which is the type strain of $C$. barati [Prévot] Holdeman and Moore 1970 [15]) that they had received from the Pasteur Institute in Paris, France.

It is not clear why Nakamura et al. continued to use the name $C$. paraperfringens for the species. Prévot's description of $I$. barati was validly published $(10)$, the species is considered legitimate (2), and the name $C$. barati appeared on the 1980 Approved Lists of Bacterial Names (15).

Perhaps Nakamura et al. did not recognize $I$. barati because the two labeled strains of $I$. barati that they studied did not have the characters reported for "le bacille de Barat" by Tissier (16). In citations of new species, Prévot often attributed the name to previous authors even though they had not named the species according to accepted rules. Thus, Prévot (10) cited the species as "I. barati (Tissier) nv. dnm." Because the species was named by Prévot, not Tissier, whether or not $C$. barati (Prévot) Holdeman and Moore is the same organism as that seen by Barat and Tissier, later described by Tissier (16) as "le bacille de Barat," has no bearing on the validity of this species.

Perhaps Nakamura et al. placed Prévot's strains of $C$. barati in their new species $C$. paraperfringens on the basis of the discrepancies from Prévot's description rather than on their first-hand analysis of authentic strains. Some taxonomists take the position that the "description" represents (i.e., "is") the species (E. F. Lessel, personal communication). Thus, the type strain (description) would remain the same, even if variation occurred in the culture as a result of continued preservation. But this position does not allow for errors in the descriptions that are based on erroneous or incomplete analytical results or are caused by technical errors, misprints, oversights, or limitations of methods. Most taxonomists take the position that the species is based on the type strain and that the description can be modified on the basis 


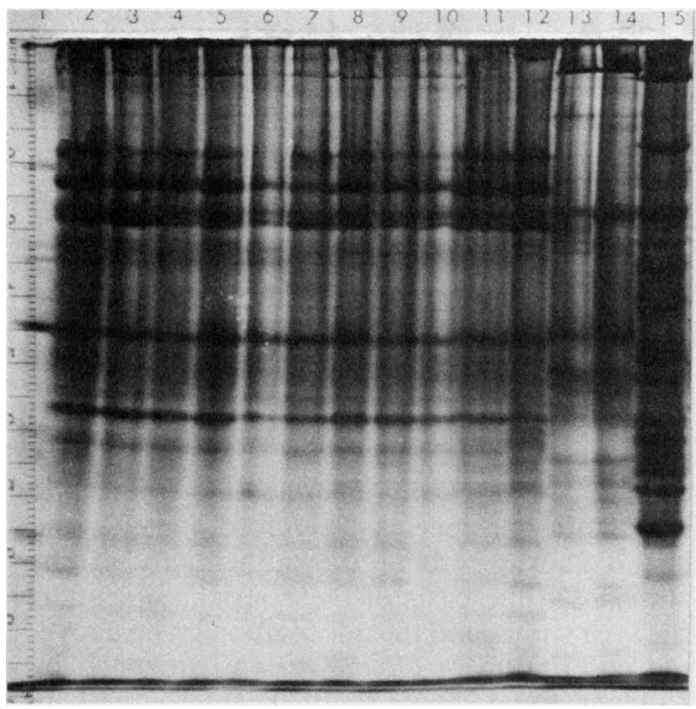

Fig. 1. Electrophoretic protein patterns of Clostridium isolates. Lane (1) reference strain U4-20 of Streptococcus faecalis; $(2,3) C$. barati 4443,4624 ; (4) C. paraperfringens 6908 ; $(5,6$, $7,8,9)$ C. perenne $4475,6921,8204,9436$, 9919; $(10,11,12) C$. paraperfringens $6907 \mathrm{~A}$, 6909A, 4846; (13, 14) C. absonum 13181, 6903A; (15) C. perfringens 5694.

of improved analyses of the type strain. If the strain really does change during storage, this too is a valid property of the species.

The discrepancies between Prévot's description and the reactions of his strains examined by Nakamura et al. and by us (lipolytic activity, fermentation of mannitol and inulin, stormy fer- mentation of milk, and fermentation products) can be explained. When Prévot described a species, he often chose to emend any previously published description by other authors rather than amend it. Since he believed his strains were similar to "le bacille de Barat" of Tissier (16), Prévot included in his description of $I$. barati some of the characteristics Tissier had listed. Prévot did not include motility (as described by Tissier) as a characteristic (his genus Inflabilis included only nonmotile species), probably because he was aware that in early work Brownian movement often was mistaken for motility. Although Tissier stated that the organism produced only acetic acid, Prévot did not report the composition of the acid products (as formic, butyric, and lactic) until 1948 (12). He believed that Duclaux distillation and earlier procedures were inaccurate for identifying mixtures of short-chained fatty acids (A. R. Prévot, personal communication). As detected by gas chromatographic analysis, the strains produced formic, acetic, butyric, and lactic acids, with traces of propionic acid. The stormy fermentation of milk was irregularly observed. We reported (3) that the reaction in milk is variable (see also Table 2 footnote and Table 3 ).

Almost certainly, Prévot included mannitol fermentation as a property of the species because Tissier stated that mannitol was fermented. We have no indication that Prévot ever detected fermentation of mannitol by any culture he recognized as $I$. barati. On our copies of his original work sheets for two of the strains, no mention is made of mannitol fermentation by Prévot strain 2227, and the record for Prévot strain 1236 bears the notation that "all except mannitol" (translated) were fermented. We ex-

\begin{tabular}{|c|c|c|c|c|c|c|c|c|c|c|c|c|c|c|}
\hline \multirow{2}{*}{ Reaction } & \multicolumn{3}{|c|}{ C. barati } & \multicolumn{6}{|c|}{ C. perenne } & \multicolumn{5}{|c|}{ C. paraperfringens } \\
\hline & Prévot ${ }^{b}$ & 4443 & 4624 & Prévot $^{c}$ & 4475 & 6921 & 8204 & 9436 & 9919 & $\begin{array}{c}\text { Nakamura } \\
\text { et al. }\end{array}$ & $6907 \mathrm{~A}$ & 6908 & $6909 \mathrm{~A}$ & 4846 \\
\hline \multicolumn{15}{|l|}{ Acid from } \\
\hline Amygdalin & & - & - & & - & - & - & $w$ & - & & - & - & $\mathbf{w}$ & - \\
\hline Arabinose & & - & - & + & - & - & - & - & - & - & - & - & - & - \\
\hline Esculin & & - & - & & - & - & - & - & - & - & $\mathbf{w}$ & $w$ & $w$ & - \\
\hline Glycogen & & $w$ & w & & - & - & - & - & - & & $\mathbf{w}$ & w & - & - \\
\hline Inulin & + & - & - & & - & - & - & - & - & - & - & - & - & - \\
\hline Mannitol & + & - & - & & - & - & - & - & - & - & - & - & - & - \\
\hline Ribose & & - & - & & - & $w$ & - & w & $w$ & $v$ & $\mathbf{w}$ & $w$ & - & - \\
\hline Starch & + & + & + & & - & - & - & - & - & + & + & + & - & - \\
\hline $\mathrm{NO}_{3}$ reduced & - & + & + & - & + & + & + & + & + & + & +- & + & + & + \\
\hline Lipase & + & - & - & & - & - & - & - & - & - & - & - & - & - \\
\hline $\mathrm{H}_{2} \mathrm{~S}$ & + & + & + & - & - & - & - & - & - & - & - & - & - & + \\
\hline \multicolumn{15}{|c|}{ 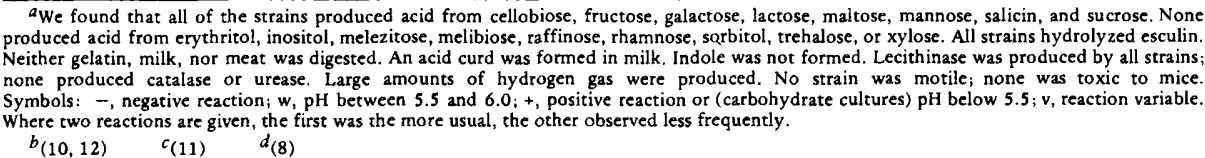 } \\
\hline
\end{tabular}


TABLE 3. Results of Babcock butterfat analyses of 8-day-old cultures in bomogenized and whole milk

\begin{tabular}{|c|c|c|c|c|}
\hline \multirow{2}{*}{ Inoculum } & \multicolumn{2}{|c|}{ Sterile homogenized cow's milk } & \multirow{2}{*}{$\frac{\text { Sterile }}{\text { Appearance }}$} & \multirow{2}{*}{$\frac{\text { goat's milk }}{\% \text { Butterfat }}$} \\
\hline & Appearance & \% Butterfat & & \\
\hline None & No change & 2.8 & Semisolid precipitate & 6.1 \\
\hline $4475 C$. perenne & Solid, smooth curd, gas & 2.1 & Hard shrunken curd & 6.0 \\
\hline 6907A C. paraperfringens & No change & 2.0 & Hard shrunken curd & 6.2 \\
\hline 4443 C. barati & No change & 2.0 & Hard shrunken curd & 5.5 \\
\hline
\end{tabular}

amined four of the eight strains he isolated (14), and none lowered the $\mathrm{pH}$ of mannitol medium. The fermentation of mannitol and inulin reported by Tissier and listed by Prévot (13) but not found by Prévot, by Nakamura et al., or by us, can be ascribed to contamination of those sugars with glucose, as was later realized, or to reduction of the $\mathrm{pH}$ indicator often used to determine acid production.

Prévot's description of $I$. barati as lipidolytic also was probably based on Tissier's description. There is no indication on our copies of Prévot's records that he ever tested these strains for this property. Tissier reported (16) that "in milk containing 41 grams of 'butter' per liter, only 26 grams were obtained after 8 days of culture" (translated). The value of this observation is questionable. Before the Babcock test was developed, a standard method for analysis of milk quality ("richness") was to determine how much butter it would yield. Although there was an apparent $36 \%$ loss of butter, butter itself is only 60 to $70 \%$ butterfat. The remainder is not fat but solids (including lecithin and protein) and water. Furthermore, butterfat is lost by natural degradation if milk is held for $\mathbf{8}$ days. Without a complete description of Tissier's analysis for butter, it is difficult to postulate how accurate determinations of the recovery of butter could be made from the incubated milk which formed dense solid curds (stormy fermentation).

Nevertheless, we ran Babcock butterfat (as opposed to butter) analyses (1) on samples of sterilized homogenized cow's milk and whole goat's milk that was inoculated and incubated for 8 days. It was necessary to break mechanically the protein clots present in some cultures. Even so, the remaining small particles probably caused analytical errors. The averages of triplicate analyses are reported in Table 3 . These observations indicate that butterfat (and probably butter yield) may decrease after 8 days of incubation.

Nakamura et al. might have questioned whether the strains received from the Pasteur Institute were authentic. However, the characteristics of the strains are those observed by
Prévot, who originally identified the strains and is author of the species. Therefore, there should be no question about the authenticity of the strains. On the basis of these strains, including the type strain, and the information given above, the description of $C$. barati was amended by Holdeman and Moore in 1970 (4) to agree with the biochemical reactions of the strains.

From our analyses of the type strains, and the DNA-DNA homology data of Nakamura et al., it is clear that $C$. paraperfringens Nakamura, Tamai, and Nishida 1970, is a synonym of Clostridium barati (Prévot) Holdeman and Moore 1970 , both of which appear in the $1980 \mathrm{Ap}$ proved Lists of Bacterial Names.

According to Rule $24 \mathrm{~b}$ of the International Code of Nomenclature of Bacteria (5): "If two names compete for priority and if both names date from 1 January 1980 on an approved list, the priority shall be determined by the date of the original publication of the name before 1 January 1980.",

Because strains (including, in each case, the type strain) of $C$. paraperfringens are homologous with those of $C$. barati (8) and the strains of $C$. barati and $C$. perenne have common morphological and biochemical properties and identical electrophoretic patterns of soluble cellular proteins which correlate well with DNA homology analyses, we propose that the names $C$. paraperfringens and $C$. perenne be rejected as later synonyms and that all of these strains be included in the species $C$. barati (Prévot 1938) Holdeman and Moore (1970). The type strain of this species is ATCC $27638(\leftarrow$ VPI $4443 \leftarrow$ Pasteur Institute 2227).

Rule $24 \mathrm{~b}$ does not indicate clearly whether priority is to be based on the binary name (as given in the 1980 List) or on the specific epithet. However, Rule 23a (Note 1) and Rule 32b clearly indicate that, in cases of priority, the specific epithet (i) is treated independently, and (ii) is not rendered illegitimate by publication as part of a binary combination in which the generic name (of the combination) is illegitimate. Thus, Inflabilis barati Prévot 1938, which was (but is not now) a legitimate binary name, would establish 
priority of the specific epithet "barati" over that in Acuformis perennis Prévot 1940 and over those in any other subsequent, related binary combinations containing the currently accepted generic name Clostridium: e.g., C. perenne (Prévot) McClung and McCoy 1957 and $C$. paraperfringens Nakamura et al. 1970. For these reasons we regard the specific epithet "barati" as having priority for the species name, even though the basonym, "Inflabilis barati," is not on the Approved Lists of Bacterial Names.

\section{ACKNOWLEDGMENTS}

We gratefully acknowledge the assistance of Donald E. Hash in the electrophoretic analyses and of Luba Fabrycky in the bacteriological analyses.

This work was supported by Public Health Service grant AI 15244-01 A from the National Institute of Allergy and Infectious Disease.

\section{REPRINT REQUESTS}

Address reprint requests to: Elizabeth $P$. Cato, Department of Anaerobic Microbiology, Virginia Polytechnic Institute and State University, Blacksburg, VA 24061.

\section{LITERATURE CITED}

1. American Public Health Association. 1960. Babcock method-official, p. 373-375. In Standard methods for the examination of dairy products, 11th ed. American Public Health Association, Inc., New York.

2. Buchanan, R. E., J. G. Holt, and E. F. Lessel, Jr. (ed.). 1966. Index bergeyana, p. 614. The Williams \& Wilkins Co., Baltimore.

3. Holdeman, L. V., E. P. Cato, and W. E. C. Moore (ed.). 1977. Anaerobe laboratory manual, 4th ed. Virginia Polytechnic Institute and State University, Blacksburg.
4. Holdeman, L. V., and W. E. C. Moore. 1970. Clostridium, p. 60. In L. V. Holdeman and W. E. C. Moore (ed.), Outline of clinical methods in anaerobic bacteriology, 2nd rev. Virginia Polytechnic Institute, Blacksburg.

5. Lapage, S. P., P. H. A. Sneath, E. F. Lessel, V. B. D. Skerman, H. P. R. Seeliger, and W. A. Clark (ed.). 1975. International code of nomenclature of bacteria. American Society for Microbiology, Washington, D.C.

6. McClung, L. S., and E. McCoy. 1957. Genus II Clostridium Prazmowski 1880 , p. 673. In Breed, Murray, and Smith (ed.), Bergey's manual of determinative bacteriology, 7th ed. The Williams \& Wilkins Co., Baltimore.

7. Moore, W. E. C., D. E. Hash, L. V. Holdeman, and E. P. Cato. 1980. Polyacrylamide slab gel electrophoresis of soluble proteins for studies of bacterial floras. Appl. Environ. Microbiol. 39:900-907.

8. Nakamura, S., T. Shimamura, M. Hayase, and S. Nishida. 1973. Numerical taxonomy of saccharolytic clostridia, particularly Clostridium perfringens-like strains: descriptions of Clostridium absonum sp. $\mathrm{n}$. and Clostridium paraperfringens. Int. J. Syst. Bacteriol. 23:419-429.

9. Nakamura, S., K. Tamai, and S. Nishida. 1970. Criteria for identification of Clostridium perfringens. 6. Clostridium paraperfringens sp. nov. Med. Biol. 80:137-140.

10. Prévot, A. R. 1938 . Études de systématique bactérienne. IV. Critique de la conception actuelle du genre Clostridium. Ann. Inst. Pasteur Paris 61:77.

11. Prévot, A. R. 1940. Recherches sur la flore anaérobie de l'intestin humain: Acuformis perennis nov. sp. C.R. Seances Soc. Biol. Paris 133:574-577.

12. Prévot, A. R. 1948. Manuel de classification et de détermination des bactéries anaérobies. Masson and Co., Paris.

13. Prévot, A. R. 1957. Manuel de classification et de détermination des bactéries anaérobies, 3rd ed. Masson and Co., Paris.

14. Prévot, A. R., A. Turpin, and P. Kaiser. 1967. Les bactéries anaérobies. Dunod, Paris

15. Skerman, V. B. D., V. MeGowan, and P. H. A. Sneath. 1980. Approved lists of bacterial names. Int. J. Syst. Bacteriol. 30:225-420.

16. Tissier, H. 1918. Le bacille de Barat. C.R. Seances Soc. Biol. Paris 81:426-427. 